Proc. 13th Econophysics Colloquium (EC) and 9th Symposium of Physics in Economy and Social Sciences (FENS), 2017

\title{
Econophysics as a Cause of a Scientific Revolution in Mainstream Economics
}

\author{
A. JAKIMOWICZ* \\ Institute of Economics, Polish Academy of Sciences, Palace of Culture and Science, \\ Pl. Defilad 1, PL-00901 Warsaw, Poland
}

\begin{abstract}
The aim of this article is to establish whether econophysics can cause a scientific revolution and fundamentally change the image of mainstream economics. Science development processes were carefully analysed by Kuhn, who even created a specific vocabulary for it. The most important phrases include paradigm and scientific community. When comparing the disciplinary matrices of econophysics and economics, it has to be stressed that despite the absolute compatibility of the goals of both sciences, econophysics is not - as postulated from time to time - a new econometric approach that entails the application of physics in studies of economics, but rather it is a scientific field totally different from economics. The disproportion between the disciplinary matrices of both sciences regards such elements as symbolic generalisations, models, values, and exemplars. Therefore, it seems that progressive accumulation of knowledge in economics will reveal new anomalies as well as deepen existing ones, making a paradigm shift inevitable. A scientific revolution should be expected at an international level, and in such countries as Poland it will be external and forced. The reasons for that lie in psychology and history. In 1989, in Poland and in other post-socialist countries, a rapid change in the disciplinary matrix of economics occurred and involved the replacement of the socialist economic paradigm with the capitalist economic paradigm. Another scientific revolution of such nature is right around the corner and entails replacing the disciplinary matrix of economics with the transdisciplinary matrix of econophysics. Since Polish economists have tried very hard to resist such a great number of changes, the paradigm shift will require deep involvement and much work from young scholars.
\end{abstract}

DOI: 10.12693 /APhysPolA.133.1339

PACS/topics: 89.65.Gh

\section{Introduction}

The origins of econophysics date back to 1995, though the concepts of physics have contributed to the development of economics since its very beginning [1]. It seems that the issue of assimilation of econophysics, which is still a new idea for economists, may be due to the normal management science placed in Kuhn's general structure of scientific revolutions [2]. In order to solve it, it is necessary to identify possible differences in the paradigms of the mainstream economics and econophysics as well as to define the principles of the functioning and collaboration of scientific communities focused on them. Of great importance is also the explanation of perception of econophysics by Polish and international economic communities as it strongly affects the development of econophysics and its practical applications, both in Poland and abroad. It also seems that a new scientific community, a result of a scientific revolution in economics, could not be hierarchical in structure as postulated by Kuhn [3].

\section{Kuhn's vocabulary}

As Kuhn suggested, a paradigm may be perceived locally or globally [4]. Paradigms are an inseparable part of scientific communities which accept them. A paradigm

\footnotetext{
${ }^{*}$ corresponding author
}

in a global sense coincides with the concept of a disciplinary matrix, which consists of four main components: symbolic generalisations, models, values, and exemplars. Symbolic generalisations are formalised matrix components of logical formulae. Models express analogies accepted by a given scientific community and sometimes even include ontological issues. Values include the criteria of rational acceptance and rejection or choice of scientific theories. Exemplars include standard examples of a community, meaning specific scientific problems and their exemplary solutions. On the other hand, a paradigm in a local sense is associated exclusively with exemplars.

Since a paradigm and a scientific community are phrases related to each other and their scope and logical sense are close to each other, to avoid a vicious circle of reasoning, scientific communities are perceived as autonomous beings. A scientific community is composed of people specialising in specific fields. A field has its own well-developed communication network, which mainly results from unanimity in professional matters. According to Kuhn, scientific communities are hierarchical in structure. The higher-level group include all scientists, whereas the lower-level groups consist of physicists, chemists and biologists. Every community consists of numerous sub-groups, but that division ends with groups of about one hundred people who carry out their academic research as part of a specific field.

The source of scientific revolutions is the disproportion between the disciplinary matrices of related disci- 
plines which grow due to the accumulation of knowledge. Anomalies play a big role in that process as they are unsolvable scientific problems under a given paradigm. They are ignored as long as possible since they often require a new vocabulary or even a completely new methodology. Accumulation of knowledge and more and more common anomalies lead to a crisis in a given science, i.e. to a period when scholars ponder the foundations of their theories. Usually, a crisis is overcome during a scientific revolution which entails replacing the old paradigm with a new one. A scientific revolution, if it occurs, is a sharp process, though changes are not necessarily immediate.

\section{The paradigms of econophysics and the mainstream economics}

Econophysics and the mainstream economics will be compared by applying the concept of a paradigm in a global sense, thus in terms of a disciplinary matrix. Table I (at the end) presents an overview of representative literature on econophysics which suggests that the goals of econophysics and economics coincide with each other because both econophysics and economics are about solving the most fundamental problems related to the functioning of markets and national economies. The central point of interest of both sciences are studies of the stability of financial markets and attempts to solve certain macroeconomic problems, especially those related to sustainable development and economic growth. The first thing to be established is whether or not, despite the same goals, the disciplinary matrices are comparable to each other.

Econometrics does not seem to be the right way of incorporating econophysics into the mainstream economics. However, econophysics and economics are so different that they have to be considered as separate sciences. Econophysics is an inductive science, based on observations; therefore, it is an empirical discipline. It entails studying how markets and economies function so empirical data are not put in a priori models. Economics is totally different. As a rule, it is a deductive science where mathematical modelling is applied; therefore, it is based on certain axiomatic systems. According to Kuhn, the disciplinary matrices of such sciences are fundamentally disproportionate. In fact, material differences come to the surface at the level of symbolic generalisations. When it comes to mathematical systems, if a logical formula is part of a problem solution, then it always looks the same. Even if it takes different form, it will be possible to reduce such a formula to its original form by the rules of substitution, identity or other syntactic rules. In empirical sciences, like econophysics, symbolic generalisations function in a different manner; in fact, they are draft generalisations being patterns and its detailed symbolic nature may vary depending on the system [4].

Differences between symbolic generalisations in economics and econophysics can be exemplified. In the mainstream economics, the main symbolic generalisation is the quantity theory of money, which assumes a relation between the amount of money in circulation and the general price level of goods and services. Usually, it is presented as follows:

$$
M V=P Y \Leftrightarrow P=\frac{M V}{Y},
$$

where $M$ - nominal money supply, $V$ - transactions velocity of money, $P$ - general price level, $Y$ - real output. Relation (1) is dubbed the equation of exchange. The quantity theory of money is also presented as the Cambridge equation

$$
\frac{M}{P}=k Y,
$$

where $k$ is part of the nominal national income $(P \cdot Y)$ kept by economic operators for convenience and security as a stock of money. If one assumes that $k$ is an inverse of transactions velocity of money being $V$, then the Cambridge Eq. (2) is the same as the equation of exchange (1).

On the other hand, in econophysics, generalisations are special patterns, an example of which may be the power laws. They can describe the wealth of entities under stable financial conditions

$$
N(s) \approx C s^{-\alpha},
$$

where $N(s)$ is a number of entities generating profit not lower than $s, C$ is a constant, and $\alpha>0$ is a critical exponent. The power laws are independent of scale. When $\tilde{s}=\varphi s, N(\tilde{s})=\tilde{C} N(s)$, thus the change of scale does not affect the basic statistical behaviours of the system. Law (3) was discovered at the end of the 19th century by Pareto, an Italian economist, who established that the relation in question is universal for $\alpha=1.5$ because it applies to incomes of societies in different countries $[118,119]$. Other symbolic generalisations very frequently employed in econophysics are market histograms.

Vast differences in symbolic generalisations result in similar differences in other components of the disciplinary matrices: models, values, and exemplars. Econophysics models are generally inductive and economic models are usually deductive. Numerous econophysicists believe that cognitive values should be empirical and the mainstream economics lacks such empiricism.

The disproportion between the paradigms is also visible when it comes to exemplars. The extent of disproportion may be demonstrated by examples. The most interesting exemplar in mainstream economics is the efficient market hypothesis. It was formulated by Samuelson, a 1970 winner of Nobel Prize in economics, who employing purely mathematical reasoning proved that capital market price fluctuations are random [120-122]. Based on the assumptions of rational behaviours of investors and efficient market, he proved that the following relation exists:

$$
E\left\{P_{t+1} \mid P_{0}, P_{1}, \ldots, P_{t}\right\}=P_{t},
$$

where $P_{t+1}$ is an expected value of securities in $t+1$, and $P_{0}, P_{1}, \ldots, P_{t}$ is prior price fluctuations. Equation (4) is true for stochastic processes called martingales. Econophysics addresses this problem in a completely different 
way; it is assumed that financial markets are complex adaptive systems. In recent years, certain deterministic mechanisms that govern the behaviours of those markets were found which, in turn, put the efficient market hypothesis in question $[123,124]$.

Accumulation of knowledge in both disciplines reveals anomalies in both the mainstream economics and econophysics. In the first case, they are already critical which can, but does not have to, precede a scientific crisis, whereas in the second case, they are spotted and remedied relatively quickly. From the economic perspective, one has to distinguish between two types of crisis: a crisis in economics (as referred to by Kuhn in his scientific revolution theory) and a crisis in the economy. Generally, the latter is a consequence of the first. Thus, the greatest anomaly in economics is a global financial crisis in terms of theory (the crisis not anticipated by Kuhn's "normal economics") and practice (the crisis leading to enormous destruction of nations' wealth).

\section{Requirements for success of the econophysics revolution}

One has to agree that econophysics triggered material changes in the understanding of economic processes. Their full and long-term evaluation is impossible at this time since the revolution is not over yet. However, one may now assess whether the new paradigm will last and be effective. Johnson formulated the effectiveness criteria for any economic revolution [125]. There are five requirements and all of them have to be met:

(1) the core elements of the existing orthodoxy have to be put in question,

(2) a new theory should include valuable elements of its predecessor,

(3) innovative beliefs should have an adequate level of difficulty in order to discourage the older generation of scientists from learning,

(4) a new and more appealing methodology has to be developed,

(5) the revolutionary theory has to address important and previously unknown empirical relations, thus laying foundations for new econometric research.

All of the foregoing were met by the Keynesian theory in the past. Let us briefly discuss whether econophysics can meet those requirements.

Table I proves that the first requirement is met since econophysics successfully solves the core economic issues in terms of the functioning of markets and the growth of national economies. The second requirement seems to be the most difficult to meet. Beside their goals, econophysics and the mainstream economics have little in common. However, the traditional economics has seen numerous non-linear models which can be studied in detail and developed using the non-linear dynamics methods. As mentioned earlier, those models could be taken over and developed in econophysics [1]. This process has already begun and one should expect the intensification of efforts in the future. The third requirement has been met, which is proved by the results presented in Table I. The analysis of professional affiliation of the listed authors proves that over $90 \%$ of them are physicists. The methodologies applied in those papers confirm that only the concepts of physics were employed. On the other hand, the mainstream economics is chiefly the field of economists, to whom methods applied by physicists are usually not familiar. The fourth requirement is obviously met as econophysics generally employs methodologies previously non-existent in economics. The fifth requirement has also been met, as may be proved by exemplars. Though one of the most essential exemplars in the mainstream economics is the market efficiency hypothesis, in econophysics there are empirical counterexamples, e.g. the fractal market hypothesis and the coherent market hypothesis [126, 127].

In evaluating future relations between econophysics and economics, three main possibilities should be taken into consideration. The first of them involves absorption of mainstream economics by econophysics, which would have to imply that economics would become one of branches of physics, such as optics or mechanics. Thus, economics as such would gradually disappear, and its most valuable components would be taken over by econophysics. The second possibility would involve the reverse phenomenon, with economics absorbing econophysics. In such a case, economics would take over methodological foundations from econophysics, which would make econophysics a declining science. The third possibility, which appears most probable, would be an intermediate solution. Currently, research scopes of both sciences resemble partly overlapping circles (with identical research objectives), while the integrity of both economics and econophysics is preserved. However, the intersection of both sets is not too large. In the future, the continuation of this status should be expected, with the intersection presumably growing. In this sense, econophysics may contribute to a revolution in economics, while most probably, both sciences will still preserve their own identity.

\section{Chances for success of the econophysics scientific revolution in Poland and abroad}

One of the first attempts at making Polish economists interested in the application of physics in economics was made in 1958 by Rawita Gawroński, a Polish economist [128]. If he had been taken seriously, perhaps today Poland would be the worldwide leader in econophysics. However, it did not happen and econophysics is barely covered in Polish literature on economics. There are only few papers discussing this discipline quite accurately [129-133]. This means that chances for success of the econophysics scientific revolution are greater abroad than in Poland.

This time, the problem in question should be tackled taking into consideration the principles of operation and cooperation of scientific communities focused on the econophysics and economics paradigms. The analysis of professional affiliation of the authors listed in Ta- 
ble I proves that the Polish community of econophysicists is part of the worldwide community of experts in that field rather than part of the Polish community of economists. The worldwide community of econophysicists is a community also separate from the worldwide group of mainstream economists, though it seems that, in this case, the boundaries between the communities are vaguer when compared to Poland. This suggests that a scientific revolution triggered by econophysics, if it occurs at all, should shift the paradigm of economics first internationally and then in Poland. From the point of view of Polish economists, a factor forcing change will be external. The situation will be similar to the situation in 1989, when external changes forced the shift of the centrally planned economy paradigm to the market economy paradigm. This implies that reasons for a possible delay in shifting the paradigm of Polish economics are mainly psychological and historical factors. Scientific revolutions, especially as fundamental as a paradigm shift in economics, cannot happen too often due to the resistance of the scientific communities to change. Meanwhile, Polish economists have not yet recovered from the effects of the 1989 scientific revolution and they are already facing another revolution. This may lead to even greater resistance; one should not be surprised that Polish economists find it difficult to embrace econophysics.

The aforementioned transformation of the disciplinary matrix in economics is very probable and fits Kuhn's pattern of scientific revolutions, but with two exceptions. The first exception concerns the structure of a new scientific community and the second exception is about the necessity to replace the disciplinary matrices with a transdisciplinary matrix.

Kuhn explicitly says that scientific communities are hierarchical in structure. Such a statement could have been deemed correct in 1962 when his fundamental work on scientific revolutions was published. No such transdisciplinary fields of science as econophysics were present then, but it is different today. The new community to be formed after the paradigm shift in economics, whose beginnings we are now witnessing, should be horizontal in structure since it would be some third group partially composed of representatives of two alreadyexisting and generally separate groups: econophysicists and economists. Other possibilities, such as absorption of one science by another, are much less likely.

New economics, which would be a result of Kuhn's scientific revolution, should entail a new kind of paradigm. It would involve replacing the traditional disciplinary matrix with something I call a transdisciplinary matrix. It would contain not only the knowledge of economics, but also the methodologies from natural sciences, particularly from physics, chemistry, and biology [134].

\section{Conclusions}

Contemporary mainstream economics needs a paradigm shift because it is producing an increasing number of anomalies. The development of economics seems to be consistent with Kuhn's pattern of scientific revolutions, though the best candidate for the cause of such a revolution seems to be econophysics because its goals are identical to the goals of economics. However, there are two exceptions. The first exception would involve a new community being horizontal in structure, and the second exception would be the necessity to implement a transdisciplinary matrix. One should expect a scientific revolution on an international scale and its impact on economics in such countries as Poland would be delayed and forced by external factors. Difficulties in the assimilation of econophysics by Polish economists are of psychological and historical nature. In 1989, a similar change in the disciplinary matrix of Polish economics occurred; it involved replacing the socialist economy paradigm with the capitalist economy paradigm. It was forced by external factors. An econophysics revolution would be of similar nature and that explains why such changes would face resistance from scientists. If there actually was a revolution, the new scientific community would consist of - apart from econophysicists economists who would work under three paradigms: socialism, capitalism, and econophysics. Since there would not be many of such people, any revolution has to be the doing of the younger generation of scholars.

\section{References}

[1] A. Jakimowicz, Acta Phys. Pol. A 129, 897 (2016).

[2] T.S. Kuhn, The Structure of Scientific Revolutions, University of Chicago Press, Chicago 1970.

[3] A. Jakimowicz, Nonlin. Dyn. Psychol. Life Sci. 13, 393 (2009).

[4] T.S. Kuhn, The Essential Tension: Selected Studies in Scientific Tradition and Change, University of Chicago Press, Chicago 1977.

[5] J.L. McCauley, Physica A 237, 387 (1997).

[6] J.L. McCauley, Discrete Dyn. Nature Soc. 1, 17 (1997).

[7] J.L. McCauley, C.M. Küffner, Discrete Dyn. Nature Soc. 2004, 213 (2004).

[8] T. Gospodarek, Acta Phys. Pol. A 117, 658 (2010).

[9] A. Jakimowicz, Acta Phys. Pol. A 117, 640 (2010).

[10] C. Mesjasz, Acta Phys. Pol. A 117, 706 (2010).

[11] P. Oświęcimka, S. Drożdż, J. Kwapień, A.Z. Górski, Acta Phys. Pol. A 123, 597 (2013).

[12] J.L. McCauley, Physica A 285, 506 (2000).

[13] J.L. McCauley, Physica A 299, 294 (2001).

[14] J.L. McCauley, Physica A 314, 722 (2002).

[15] J.L. McCauley, Physica A 329, 199 (2003).

[16] A. Jakimowicz, Acta Phys. Pol. A 121, B-50 (2012).

[17] A. Jakimowicz, J. Juzwiszyn, Acta Phys. Pol. A 127, A-78 (2015).

[18] D. Canning, L.A.N. Amaral, Y. Lee, M. Meyer, H.E. Stanley, Econ. Lett. 60, 335 (1998).

[19] E. Gaffeo, M. Gallegati, G. Giulioni, A. Palestrini, Physica A 324, 408 (2003). 
[20] D. Sornette, W.-X. Zhou, Physica A 332, 412 (2004).

[21] H.E. Stanley, V. Afanasyev, L.A.N. Amaral, S.V. Buldyrev, A.L. Goldberger, S. Havlin, H. Leschhorn, P. Maass, R.N. Mantegna, C.-K. Peng, P.A. Prince, M.A. Salinger, M.H.R. Stanley, G.M. Viswanathan, Physica A 224, 302 (1996).

[22] H.E. Stanley, L.A.N. Amaral, X. Gabaix, P. Gopikrishnan, V. Plerou, Physica A 302, 126 (2001).

[23] H.E. Stanley, L.A.N. Amaral, P. Gopikrishnan, P.C. Ivanov, T.H. Keitt, V. Plerou, Physica A 281, 60 (2000).

[24] B. Jackowska-Zduniak, U. Grzybowska, A. Orłowski, Acta Phys. Pol. A 127, A-70 (2015).

[25] A. Jakimowicz, Acta Phys. Pol. A 127, A-86 (2015).

[26] Ł. Lenart, M. Pipień, Acta Phys. Pol. A 123, 567 (2013).

[27] J. Miśkiewicz, Acta Phys. Pol. A 123, 589 (2013).

[28] J. Miśkiewicz, Acta Phys. Pol. A 127, A-103 (2015).

[29] P. Skowron, M. Karpiarz, A. Fronczak, P. Fronczak, Acta Phys. Pol. A 127, A-123 (2015).

[30] M. Snarska, Acta Phys. Pol. A 121, B-110 (2012).

[31] S. Drożdż, J. Kwapień, P. Oświęcimka, J. Speth, Acta Phys. Pol. A 114, 539 (2008).

[32] J. Miśkiewicz, M. Ausloos, Physica A 336, 206 (2004).

[33] J. Miśkiewicz, M. Ausloos, Acta Phys. Pol. B 36 2477 (2005).

[34] M. Nicolov, Proced. Econ. Finance 6, 754 (2013).

[35] A.M. Petersen, B. Podobnik, D. Horvatic, H.E. Stanley, EPL A, Lett. J. Explor. Frontiers Phys. 90, 38006 (2010).

[36] B. Podobnik, V. Vukovic, H.E. Stanley, Plos One 10, e0141211 (2015).

[37] A. Jakimowicz, D. Rzeczkowski, Acta Phys. Pol. A 129, 1011 (2016).

[38] A. Kożuch, B. Kożuch, K. Sienkiewicz-Małyjurek, $H y$ perion Int. J. Econophys. New Econ. 7, 293 (2014).

[39] T. Mizuno, M. Takayasu, H. Takayasu, Physica A 308, 411 (2002).

[40] D. Sornette, H. Takayasu, W.-X. Zhou, Physica A 325, 492 (2003).

[41] A. Yasutomi, Physica D 82, 180 (1995).

[42] A. Yasutomi, Chaos 13, 1148 (2003).

[43] R. Gębarowski, S. Drożdż, A.Z. Górski, P. Oświęcimka, Acta Phys. Pol. A 127, A-51 (2015).

[44] A.Z. Górski, S. Drożdż, P. Oświęcimka, Acta Phys. Pol. A 117, 676 (2010).

[45] M. Ausloos, N. Vandewalle, P. Boveroux, A. Minguet, K. Ivanova, Physica A 274, 229 (1999).

[46] G.R. Richards, Physica A 282, 325 (2000).

[47] N. Vandewalle, M. Ausloos, Eur. Phys. J. B 4, 257 (1998).

[48] K. Bień-Barkowska, Acta Phys. Pol. A 127, A-7 (2015).

[49] A.Z. Górski, S. Drożdż, J. Kwapień, P. Oświęcimka, Acta Phys. Pol. B 37, 2987 (2006).

[50] A.Z. Górski, J. Kwapień, P. Oświęcimka, S. Drożdż, Acta Phys. Pol. A 114, 531 (2008).
[51] S. Gworek, J. Kwapień, S. Drożdż, Acta Phys. Pol. A 117, 681 (2010).

[52] P. Jaworski, Acta Phys. Pol. B 37, 3005 (2006).

[53] E.M. Syczewska, Acta Phys. Pol. A 121, B-121 (2012).

[54] J.-P. Bouchaud, R. Cont, Eur. Phys. J. B 6, 543 (1998).

[55] P. Gopikrishnan, V. Plerou, L.A.N. Amaral, M. Meyer, H.E. Stanley, Phys. Rev. E 60, 5305 (1999).

[56] F. Lillo, J.D. Farmer, R.N. Mantegna, Nature 421 , 129 (2003).

[57] J.D. Farmer, S. Joshi, J. Econ. Behav. Organizat. 49, 149 (2002).

[58] E. Haven, Physica A 324, 201 (2003).

[59] V. Plerou, P. Gopikrishnan, B. Rosenow, L.A.N. Amaral, H.E. Stanley, Physica A 279, 443 (2000).

[60] D. Sornette, Computer Phys. Commun. 147, 19 (2002).

[61] D. Sornette, Phys. Rep. 378, 1 (2003a).

[62] D. Sornette, Why Stock Markets Crash: Critical Events in Complex Financial Systems, Princeton University Press, Princeton 2003b.

[63] D. Sornette, A. Johansen, Quantitat. Finance 1, 452 (2001).

[64] D. Sornette, W.-X. Zhou, Quantitat. Finance 2, 468 (2002).

[65] H.E. Stanley, Physica A 285, 1 (2000).

[66] H.E. Stanley, Physica A 318, 279 (2003).

[67] H.E. Stanley, L.A.N. Amaral, D. Canning, P. Gopikrishnan, Y. Lee, Y. Liu, Physica A 269, 156 (1999).

[68] H.E. Stanley, L.A.N. Amaral, X. Gabaix, P. Gopikrishnan, V. Plerou, Physica A 299, 1 (2001).

[69] H.E. Stanley, P. Gopikrishnan, V. Plerou, L.A.N Amaral, Physica A 287, 339 (2000).

[70] N. Vandewalle, M. Ausloos, P. Boveroux, A. Minguet, Eur. Phys. J. B 4, 139 (1998).

[71] W.-X. Zhou, D. Sornette, Physica A 330, 543 (2003a).

[72] W.-X. Zhou, D. Sornette, Physica A 330, 584 (2003b).

[73] W.-X. Zhou, D. Sornette, Physica A 348, 428 (2005).

[74] B. Bieda, P. Chodorowski, D. Grech, Acta Phys. Pol. A 121, B-7 (2012).

[75] T. Ciepliński, A. Dominiczak, R. Kutner, Acta Phys. Pol. A 121, B-24 (2012).

[76] Ł. Czarnecki, D. Grech, Acta Phys. Pol. A 117, 623 (2010).

[77] M. Denys, T. Gubiec, R. Kutner, Acta Phys. Pol. A 123, 513 (2013).

[78] D. Grech, G. Pamuła, Acta Phys. Pol. A 123, 529 (2013).

[79] K. Karpio, P. Łukasiewicz, A. Orłowski, Acta Phys. Pol. A 121, B-61 (2012).

[80] K. Karpio, P. Łukasiewicz, A. Orłowski, T. Ząbkowski, Acta Phys. Pol. A 123, 553 (2013).

[81] K. Karpio, A.J. Orłowski, P. Łukasiewicz, Acta Phys. Pol. A 117, 619 (2010).

[82] M. Kozłowska, R. Kutner, Acta Phys. Pol. B 37, 3027 (2006). 
[83] M. Kozłowska, R. Kutner, Acta Phys. Pol. A 117, 630 (2010).

[84] J. Kwapień, S. Drożdż, A.Z. Górski, P. Oświęcimka, Acta Phys. Pol. B 37, 3039 (2006).

[85] J. Kwapień, S. Drożdż, P. Oświęcimka, Acta Phys. Pol. B 36, 2423 (2005).

[86] P. Oświęcimka, S. Drożdż, J. Kwapień, A.Z. Górski, Acta Phys. Pol. A 117, 637 (2010).

[87] P. Oświęcimka, J. Kwapień, S. Drożdż, A.Z. Górski, R. Rak, Acta Phys. Pol. B 37, 3083 (2006).

[88] A. Jakimowicz, A. Baklarz, Acta Phys. Pol. A 129, 980 (2016).

[89] J.A. Lipski, R. Kutner, Acta Phys. Pol. A 123, 584 (2013).

[90] R. Rak, S. Drożdż, J. Kwapień, P. Oświęcimka, Acta Phys. Pol. B 36, 2459 (2005)

[91] R. Rak, S. Drożdż, J. Kwapień, P. Oświęcimka, Acta Phys. Pol. B 37, 3123 (2006).

[92] M. Sawa, D. Grech, Acta Phys. Pol. A 127, A-118 (2015).

[93] A. Szmagliński, Acta Phys. Pol. A 123, 621 (2013).

[94] A. Szmagliński, Acta Phys. Pol. A 127, A-136 (2015).

[95] A. Sienkiewicz, T. Gubiec, R. Kutner, Z.R. Struzik, Acta Phys. Pol. A 123, 615 (2013).

[96] D. Fiaschi, M. Marsili, in: Econophysics \&s Economics of Games, Social Choices and Quantitative Techniques, Eds. B. Basu, B.K. Chakrabarti, S.R. Chakravarty, K. Gangopadhyay, Springer Science \& Business Media, Dordrecht 2010, p. 61.

[97] S. Bwanakare, Acta Phys. Pol. A 117, 647 (2010).

[98] J.-P. Bouchaud, M. Mézard, Physica A 282, 536 (2000).

[99] F. Clementi, M. Gallegati, Physica A 350, 427 (2005).

[100] A. Drăgulescu, V.M. Yakovenko, Physica A 299, 213 (2001).

[101] M. Levy, S. Solomon, Physica A 242, 90 (1997).

[102] S. Sinha, Physica A 359, 555 (2006).

[103] K. Gajowniczek, K. Karpio, P. Łukasiewicz, A. Orłowski, T. Ząbkowski, Acta Phys. Pol. A 127, A-38 (2015)

[104] M. Jagielski, R. Duczmal, R. Kutner, Acta Phys. Pol. $A$ 127, A-75 (2015).

[105] M. Jagielski, R. Kutner, Acta Phys. Pol. A 117, 615 (2010).

[106] M. Jagielski, R. Kutner, Acta Phys. Pol. A 123, 538 (2013).

[107] M. Jagielski, R. Kutner, M. Pęczkowski, Acta Phys. Pol. A 121, B-47 (2012).

[108] P. Łukasiewicz, K. Karpio, A. Orłowski, Acta Phys. Pol. A 121, B-82 (2012).

[109] L.A.N. Amaral, P. Gopikrishnan, V. Plerou, H.E. Stanley, Physica A 299, 127 (2001).
[110] G. Bottazzi, A. Secchi, Physica A 324, 213 (2003).

[111] A. Buda, A. Jarynowski, Acta Phys. Pol. A 123, 547 (2013).

[112] J. Chudziak, Acta Phys. Pol. A 123, 508 (2013).

[113] M. Ausloos, P. Clippe, A. Pękalski, Physica A 324, 330 (2003).

[114] K. Urbanowicz, J.A. Hołyst, P. Richmond, Acta Phys. Pol. A 114, 501 (2008).

[115] W.-X. Zhou, D. Sornette, Physica A 329, 249 (2003).

[116] M. Bełej, S. Kulesza, Acta Phys. Pol. A 123, 497 (2013).

[117] S. Kulesza, M. Bełej, Acta Phys. Pol. A 127, A-99 (2015).

[118] V. Pareto, Cours d'économie politique, Vol. 2, in Oeuvres complètes, Eds. G.-H. Bousquet, G. Busino, Vol. 1, Librairie Droz, Genève 1964, p. 304 (in French).

[119] V. Pareto, Manual of Political Economy, Macmillan, London 1971.

[120] P.A. Samuelson, Industr. Manage. Rev. 6, 41 (1965).

[121] P.A. Samuelson, Siam Rev. 15, 1 (1973).

[122] P.A. Samuelson, Bell J. Econ. Manage. Sci. 4, 369 (1973).

[123] J.V. Andersen, D. Sornette, Europhys. Lett. 70, 697 (2005).

[124] A. Jakimowicz, J. Juzwiszyn, Acta Phys. Pol. A 121. B-54 (2012).

[125] H.G. Johnson, Am. Econ. Rev. 61, 1 (1971).

[126] E.E. Peters, Fractal Market Analysis. Applying Chaos Theory to Investment and Economics, Wiley, New York 1994

[127] T. Vaga, Profiting from Chaos. Using Chaos Theory for Market Timing, Stock Selection, and Option Valuation, McGraw-Hill, New York 1994.

[128] Z. Rawita Gawroński, Ekonomista 6, 1691 (1958) (in Polish).

[129] A. Jakimowicz, in: Economic Sciences in the Contemporary World, Eds. B. Fiedor, Z. Hockuba, PTE, Warszawa 2009, p. 260 (in Polish).

[130] J. Juzwiszyn, in Ref. [129], p. 285 (in Polish).

[131] J. Juzwiszyn, in: , Eds. D. Kiełczewski, B. Dobrzańska, Wydawnictwo Wyższej Szkoły Ekonomicznej w Białymstoku, Białystok 2009, p. 38 (in Polish).

[132] A. Jakimowicz, in: Economic Sciences. Stylized Facts and Contemporary Challenges, Ed. B. Fiedor, PTE, Warszawa 2015, p. 103 (in Polish).

[133] P. Fiedor, A. Hołda, Studia Ekonomiczne 1, 108 (2015) (in Polish).

[134] A. Jakimowicz, The New Economics. Complex Systems and Homo Compositus, Wydawnictwo Naukowe PWN, Warszawa 2016 (in Polish). 
TABLE I

Major directions in research in econophysics in the world and in Poland.

\begin{tabular}{|c|c|c|}
\hline \multirow{2}{*}{$\begin{array}{c}\text { Subject } \\
\text { (developmental directions) }\end{array}$} & \multicolumn{2}{|c|}{ Authors, publication date and bibliographic item } \\
\hline & World econophysics & Polish econophysics \\
\hline $\begin{array}{l}\text { methodological and cogni- } \\
\text { tive issues in economics }\end{array}$ & $\begin{array}{l}\text { McCauley }(1997) \rightarrow[5,6] \\
\text { McCauley and Küffner }(2004) \rightarrow[7]\end{array}$ & $\begin{array}{l}\text { Gospodarek }(2010) \rightarrow[8] \\
\text { Jakimowicz }(2010) \rightarrow[9] \\
\text { Mesjasz }(2010) \rightarrow[10] \\
\text { Oświęcimka, Drożdż, Kwapień and Górski } \\
(2013) \rightarrow[11]\end{array}$ \\
\hline 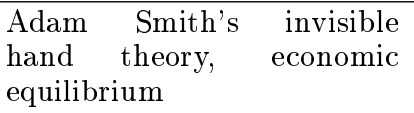 & McCauley $(2000,2001,2002,2003) \rightarrow[12-15]$ & $\begin{array}{l}\text { Jakimowicz }(2012) \rightarrow[16] \\
\text { Jakimowicz and Juzwiszyn }(2015) \rightarrow[17]\end{array}$ \\
\hline \multirow[t]{2}{*}{$\begin{array}{l}\text { business fluctuations, indi- } \\
\text { cators of economic activ- } \\
\text { ity, economic growth, for- } \\
\text { eign trade, environmental } \\
\text { protection }\end{array}$} & $\begin{array}{l}\text { Canning, Amaral, Lee, Meyer and Stanley } \\
(1998) \rightarrow[18] \\
\text { Gaffeo, Gallegati, Giulioni and Palestrini } \\
(2003) \rightarrow[19] \\
\text { Sornette and Zhou }(2004) \rightarrow[20] \\
\text { Stanley, Afanasyev, Amaral, Buldyrev, Gold- } \\
\text { berger, Havlin, Leschhorn, Maass, Man- } \\
\text { tegna, Peng, Prince, Salinger, Stanley and } \\
\text { Viswanathan (1996) } \rightarrow \text { [21] } \\
\text { Stanley, Amaral, Gabaix, Gopikrishnan and } \\
\text { Plerou (2001) } \rightarrow \text { [22] } \\
\text { Stanley, Amaral, Gopikrishnan, Ivanov, Keitt } \\
\text { and Plerou }(2000) \rightarrow[23]\end{array}$ & $\begin{array}{l}\text { Jackowska-Zduniak, Grzybowska } \\
\text { Orłowski }(2015) \rightarrow[24] \\
\text { Jakimowicz }(2015) \rightarrow[25] \\
\text { Lenart and Pipień }(2013) \rightarrow[26] \\
\text { Miśkiewicz }(2013,2015) \rightarrow[27,28] \\
\text { Skowron, Karpiarz, Fronczak and Fronczak } \\
(2015) \rightarrow[29] \\
\text { Snarska }(2012) \rightarrow[30]\end{array}$ \\
\hline & $\begin{array}{l}\text { Drożdż, Kwapień, Oświęcimka and Speth }(2008 \\
\text { Miśkiewicz and Ausloos }(2004,2005) \rightarrow[32,33]\end{array}$ & $\rightarrow[31]$ \\
\hline public sector & $\begin{array}{l}\text { Nicolov }(2013) \rightarrow[34] \\
\text { Petersen, Podobnik, Horvatic and Stanley } \\
(2010) \rightarrow[35] \\
\text { Podobnik, Vukovic and Stanley }(2015) \rightarrow[36]\end{array}$ & $\begin{array}{l}\text { Jakimowicz and Rzeczkowski }(2016) \rightarrow[37] \\
\text { Kożuch, Kożuch and Sienkiewicz-Małyjurek } \\
(2014) \rightarrow[38]\end{array}$ \\
\hline money, hyperinflation & $\begin{array}{l}\text { Mizuno, Takayasu and Takayasu }(2002) \rightarrow[39] \\
\text { Sornette, Takayasu and Zhou }(2003) \rightarrow[40] \\
\text { Yasutomi }(1995,2003) \rightarrow[41,42]\end{array}$ & $\begin{array}{l}\text { Gębarowski, Drożdż, Górski and Oświęcimka } \\
(2015) \rightarrow[43] \\
\text { Górski, Drożdż and Oświęcimka }(2010) \rightarrow[44]\end{array}$ \\
\hline $\begin{array}{l}\text { exchange markets, percent- } \\
\text { age rates }\end{array}$ & $\begin{array}{l}\text { Ausloos, Vandewalle, Boveroux, Minguet and } \\
\text { Ivanova }(1999) \rightarrow[45] \\
\text { Richards }(2000) \rightarrow[46] \\
\text { Vandewalle and Ausloos }(1998) \rightarrow[47]\end{array}$ & $\begin{array}{l}\text { Bień-Barkowska }(2015) \rightarrow[48] \\
\text { Górski, Drożdż, Kwapień and Oświęcimka } \\
(2006) \rightarrow[49] \\
\text { Górski, Kwapień, Oświęcimka and Drożdż } \\
(2008) \rightarrow[50] \\
\text { Gworek, Kwapień and Drożdż }(2010) \rightarrow[51] \\
\text { Jaworski }(2006) \rightarrow[52] \\
\text { Syczewska }(2012) \rightarrow[53]\end{array}$ \\
\hline
\end{tabular}


TABLE I (cont.)

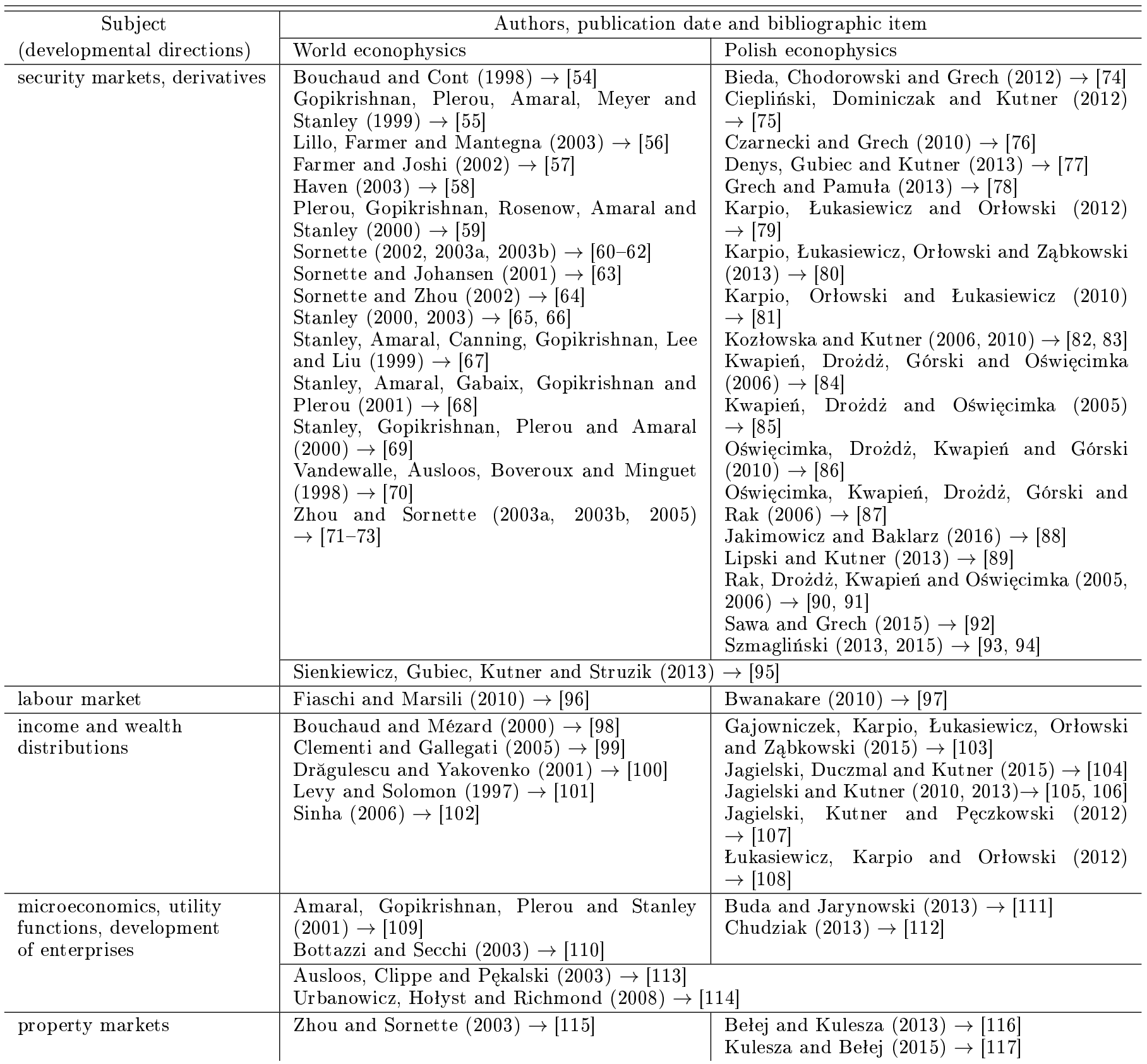

